ZOOLOGIA 30 (2): 143-150, April, 2013

http://dx.doi.org/10.1590/S1984-46702013000200004

\title{
Biology and life table of Dirphia araucariae (Lepidoptera: Saturniidae): a herbivore of potentially high impact on Araucaria angustifolia
}

\author{
Mauricio M. Zenker ${ }^{1}$, Alexandre Specht ${ }^{2,3}$, Edegar Fronza3 ${ }^{3}$, Graziela Poletto ${ }^{3}$, \\ Fernanda Marcon ${ }^{4}$, Aline C. Formentini ${ }^{3} \&$ Mateus Gedoz $^{4}$
}

\author{
${ }^{1}$ Laboratório de Dinâmica Evolutiva e Sistemas Complexos, Universidade Federal do Paraná. Caixa Postal 19020, \\ 81531-980 Curitiba, PR, Brazil. E-mail: maurizenker@gmail.com \\ ${ }^{2}$ Embrapa Cerrados. Rodovia BR 020, km 18, Caixa Postal 08223, 73310-970 Planaltina, DF, Brazil. \\ E-mail: alexandre.specht@embrapa.br \\ ${ }^{3}$ Instituto de Biotecnologia, Universidade de Caxias do Sul. Caixa Postal 1352, 95070-560 Caxias do Sul, RS, Brazil. \\ E-mail: fronzabio@yahoo.com.br, grazi.poletto@yahoo.com.br, aline.formentini@yahoo.com.br \\ ${ }^{4}$ Laboratório de Biologia, Centro de Ciências Exatas e da Natureza, Campus Universitário da Região dos Vinhedos, Universidade \\ de Caxias do Sul. Caixa Postal 32,95700-000 Bento Gonçalves, RS, Brazil.fmarcon_bio@yahoo.com.br, mgedoz@gmail.com
}

\begin{abstract}
The life-history and biology of Dirphia araucariae Jones, 1908, including its life fertility table, are here described. Moths were reared in the laboratory under controlled conditions on their host plant, Araucaria angustifolia (Bertoloni) $\mathrm{O}$. Kuntze - Araucariaceae. We describe several life-history traits of the species, namely: developmental period, survival rate, growth rate, fertility, fecundity, sex ratio, cephalic capsule width, and pupal weight. Mean duration of life stages were: egg $=26.78$ days; larva $=61.78$ days; prepupa $=6.85$ days; pupa $=62.46$ days; adult $=8.37$ days. We found statistically significant differences between sexes for adult, larval and pupal stage duration; larval stage was longer in females while pupal stage was longer in males. The survival rate of each life stage was: egg $=96.18 \%$; larva $=95.38 \%$; prepupa $=$ $83.87 \%$; pupa $=100 \%$. The larvae developed through six instars and the mean growth rate was 1.418 . The width of male and female cephalic capsules were different in last three instars, even though the total mean width between sexes was not different. Pupal mean weight ranged from $2.40 \mathrm{~g}$ to $4.79 \mathrm{~g}$, with females being heavier than males. Fertility ranged from $66.78 \%$ to $100 \%$, and the total fecundity was 358.45 eggs/female, including both laid eggs and eggs held in the abdomen. The sex ratio was $0.50 \pm 0.05$. The estimated biotic potential was 48731.08 specimens/female/year. We found the following values for the fertility life table: $(R o)=117.21$ females; $(T)=162.75$ days; $\left(r_{m}\right)=0.21 ;(\lambda)=1.23$. Considering the biological parameters evaluated in this study, we conclude that $D$. araucariae is not able to cause primary damage in $A$. angustifolia forests, although further studies are needed to understand the reasons for occasional population outbreaks.
\end{abstract}

KEY WORDS. Atlantic Forest; conservation biology; developmental biology; forest entomology; Pinheiro-do-Paraná; South America.

The Hemileucinae is the largest subfamily of Saturniidae, with 670 species and 49 genera, occurring from Nicaragua to Argentina. One of the most peculiar and well-known species of Hemileucinae moths is Dirphia araucariae Jones, 1908 due to the larval monophagous feeding habits, which are restricted to Pinheiro-do-Paraná needles - Araucaria angustifolia (Bertol.) Kuntze, Araucariaceae. The Pinheiro-do-Paraná is the dominant tree species of the Araucaria Pine Forest, the typical phytophysiognomy of Southern Brazil and nearby areas in Argentina and Paraguay. The original geographical range of $A$. angustifolia has been estimated as nearly $200,000 \mathrm{~km}^{2}$, yet nowadays only $3 \%$ of this area remains due to logging and the development of agriculture (ENRIGHT \& HiLl 1995). As A. angustifolia has high quality wood, many efforts were undertaken to culti- vate it, and also to preserve it, since it is considered a critically endangered species according to the IUCN red list (FARJON 2006).

Larvae of $D$. araucariae are voracious, being capable of eating almost all leaves of an $A$. angustifolia tree during population outbreaks. Therefore, it is known that $D$. araucariae is capable of causing serious damages on native A. angustifolia forests, as well as reaching the economic damage level on plantation forests, as reported in several occasions (Matros 1972, Macedo 1977, Borges, 1985, 1986a, Borges \& Macedo 1986). Regarding its potential to cause damage, several laboratories and field studies have been carried out to describe the main biological aspects of this species, including surveys on its natural enemies (Vila \& Carvalho 1972, Borges 1985, 1986a, b, 1988, 1990a, b, Borges \& Macedo 1986, Borges et al. 1986, Specht et al. 
2008). Although the data of the previously mentioned publications are still valid today, no study to date has generated a fertility life table with an extensive discussion on the developmental biology of $D$. araucariae. In addition, all the publications are unavailable in English, thus restricting the access to that information.

This work is part of a long term research project on Hemileucinae moths to understand their developmental biology, providing valuable information for agricultural and forest entomology, conservation biology, ecology, and taxonomy. Our goal is to independently estimate the main biological parameters of $D$. araucariae based on our own laboratory rearing, to report this information as fertility life table and to compare our results to previous studies on $D$. araucariae and other saturniid moths.

\section{MATERIAL AND METHODS}

A colony of $D$. araucariae was established at Universidade de Caxias do Sul (UCS), Campus Universitário da Região dos Vinhedos (CARVI), in the municipality of Bento Gonçalves, Rio Grande do Sul, Brazil (2908' 997"S, 51³1'392"W; 675m a.s.l.), from insects captured next to light sources in the vicinity of CARVI. All experiments were undertaken under controlled laboratory conditions at $20 \pm 1^{\circ} \mathrm{C}, 70 \pm 10 \% \mathrm{RU}$, and $12: 12$ photoperiod, in accordance with Borges (1986a). The mean duration of egg stage and fertility (defined as the number of eggs that actually become larvae) were determined from data collected from 25 egg clusters, ranging from 122 to 421 eggs. To avoid biases, the egg clusters were obtained from 19 females that had been newly captured next to light sources at CARVI, considering that laboratory-reared Hemileucinae moths, including $D$. araucariae, usually lay a smaller number of eggs (lower fecundity) than free-living moths (SРесHT et al. 2006b). Females were maintained in cages with their host plant until they laid their eggs in the surface of Pinheiro-do-Paraná needles. Twigs containing the egg clusters were set apart and transferred to 500-mL plastic cups lined with moistened filter paper, which were kept moistened every day. To avoid first instar larvae from feeding on old leaves, due to the long development to hatching, additional twigs of the host plant were available when the larvae started to eat their eggshells.

The parameters evaluated during the larval stage were based on the data collected from 186 larvae from the same egg cluster. Neonate larvae were kept together until they completed the first instar because their gregarious behavior. Each larva was carefully transferred to a new twig as soon as the second cephalic capsule hardened. In some cases, to avoid handling them, the twigs had to be set apart and then transferred to individual cups. The duration of each instar was recorded and the shed cephalic capsules of all larvae were collected. However, only the data of larvae which completed their life-cycle were used in the analysis. Each larva was identified and monitored separately from each other until pupal stage, when sex was determined according to shape and position of genital openings. This procedure allowed us to evaluate the biological parameters from both sexes, even during their larval stage. When larvae ceased feeding and changed to a darker color at the end of the larval stage (or prepupa stage), each larva was transferred to a 5-L plastic cup filled with litter from the nearest $A$. angustifolia forest. In order to sustain the appropriate relative humidity to avoid fungus proliferation, and to record when each larva had molted and turned into a pupa/adult stage, the cups were covered with a plastic film during the night, which normally is the period when the larvae feeds, and opened during the day. By using large plastic cups, we avoided changing the food frequently. A new twig was offered every day, giving enough time to the larva transfer itself from the old to the new twig to avoid excessive handling. The twigs offered at the beginning of the larval development were all 15 to $20 \mathrm{~cm}$ long, mature Pinheiro-do-Paraná needles, but the twigs offered at the end of the development were longer, (25 to $40 \mathrm{~cm}$ ) because larvae required more food at this stage. Accidentally, 56 larvae died during food replacement and were not considered in the analysis. The deaths happened because Pinheiro-do-Paraná needles are very sharp and can easily cause damage to the larvae.

The developmental period was evaluated for each sex during pupal stage and for pupal + larval stage; the survivorship rate and weight of males and females were evaluated separately for the pupal stage. The sex ratio was determined using data collected from 398 larvae from 11 egg clusters laid by different females. We calculated the growth rate by dividing the average head capsules width of the next instar by the average head capsules width of the previous instar.

Survivor rate and the duration of pre, post and oviposition period were evaluated during the adult stage. Fecundity (i.e., number of eggs produced by the female) was determined as the number of laid eggs, the number of eggs held in the abdomen and total number of eggs produced by female, according to observations made by SANTOS et al. (1988) on Hylesia nanus (Walker, 1855). To avoid bias, our data set consisted of information on 20 laboratory-reared couples (F1 generation), because it was not possible to identify whether newly captured females had already laid eggs.

The biotic potential and life fertility table were calculated using the equations from Silveira Neto et al. (1976). For the fertility table, the net reproductive rate (Ro), the mean duration of one generation $(\mathrm{T})$, the innate capacity of increase in numbers (rm) and the finite rate of natural increase $(\lambda)$ were calculated. The biotic potential (BP) was calculated considering, sex ratio (sr), total fecundity/survival rate (d), number of generations/year (n) and environmental resistance (ER). We assumed that there was no ER while the insects were reared at the laboratory. The biological parameters were compared through means and mean standard deviations; when necessary the means were compared using $t$ tests; significance was 
accepted with $p \leqslant 0.05$. The sex ratio was compared with a $1: 1$ ratio by chi-square test; significance was accepted with $\mathrm{p} \leqslant 0.01$. When necessary correlation between biological parameters were tested using Pearson's correlation coefficient. Vouchers of all stages of development were deposited at the collection of the Biology Lab of CARVI; images were obtained for all stages of development (Fig. 1).

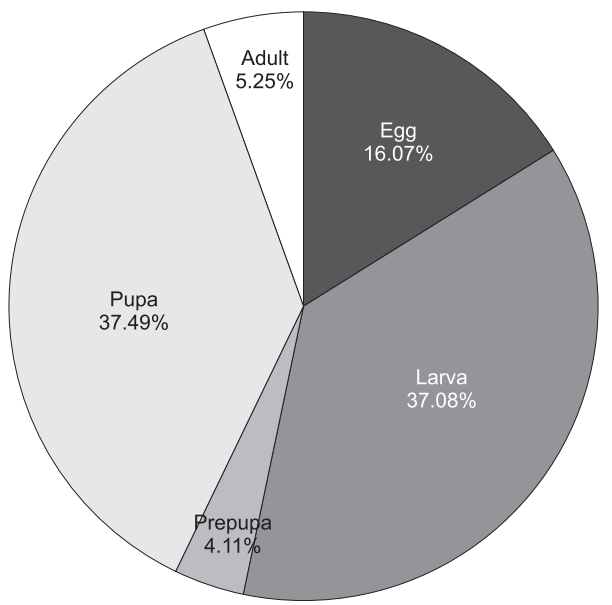

Figure 1. Proportion of each developmental stage in relation to the whole life cycle duration of Dirphia araucariae reared at $20 \pm$ $1{ }^{\circ} \mathrm{C}, 70 \pm 10 \% \mathrm{RU}$ with $12: 12$ photoperiod.

\section{RESULTS AND DISCUSSION}

The life cycle duration of $D$. araucariae was approximately 18 days longer than the observed by Borges (1986a) at the same temperature (Table I). Two reasonable explanations can be formulated to explain this discrepancy: 1) considering that the specimens used in both works were collected from locations situated hundreds of kilometers apart we can attribute this difference to intrinsic biological differences between geographical populations; or 2) differences between rearing conditions in both works could be affected the recorded biological parameters. Further studies comparing biology of different populations of $D$. araucariae under the same rearing conditions, and the use of molecular techniques to study genetic population structure could be especially useful to answer these questions and explain the reasons of eventual population outbreaks.

The life cycle duration of closely related species of $D$. araucariae [e.g., Dirphia moderata Bouvier, 1919 (ZANUncio et al. 1994, Pereira et al. 2008), Cerodirphia rosacordis (Walker, 1855) (ZANuncio et al. 1992) and Pseudodirphia eumedidoides (Vuillot, 1892) (SANTOs et al. 1993)] reared at $25^{\circ} \mathrm{C}$ ranged from approximately 110 to 140 days, and therefore might be comparable to our results (Table I). In particular, the proportion of each developmental stage in relation to the whole life cycle duration in D. araucariae (Fig. 1) were similar to that of closely related species (i.e., egg: 15\%; larva: 35-40\%; prepupa: 5\%; pupa: 25$30 \%$; adult: $5-10 \%$ ), except for prepupa and pupa stages, and may vary according to the host plant as noted by Borges (1986a).

Table I. Survival rate and mean duration of each developmental stage of Dirphia araucariae reared at $20 \pm 1{ }^{\circ} \mathrm{C}, 70 \pm 10 \% \mathrm{RU}$ with 12:12 photoperiod.

\begin{tabular}{lcccc}
\hline $\begin{array}{c}\text { Development } \\
\text { stage }\end{array}$ & $\begin{array}{c}\mathrm{N} \\
\text { (initial-final) }\end{array}$ & $\begin{array}{c}\text { Survival } \\
(\%)\end{array}$ & $\begin{array}{c}\text { Duration } \\
\text { (days) }\end{array}$ & $\begin{array}{c}\text { Range } \\
\text { (days) }\end{array}$ \\
\hline Total & - & 76.94 & 166.62 & - \\
Adult & 26 & - & $8.38 \pm 2.10$ & $5-12$ \\
Pupa & $104-104$ & 100.00 & $62.462 \pm 7.45$ & $46-79$ \\
Prepupa & $124-104$ & 83.87 & $6.846 \pm 1.16$ & $4-9$ \\
Larva & $130-124$ & 95.39 & $61.779 \pm 2.43$ & $57-69$ \\
Egg & $6784-6510$ & 96.18 & $26.779 \pm 0.39$ & $25-29$ \\
\hline
\end{tabular}

\section{Egg Stage}

The time between egg laying (Fig. 2) and hatching, corresponding to $16.07 \%$ of all developmental period (Fig. 1, Table I), was slightly longer than that observed by Borges (1986a). The fertility of the 25 egg clusters from the 19 field-collected females (6.71 eggs) was $96.18 \% \pm 6.71 \%$ and ranged from $66.78 \%$ to $100 \%$. This result is considerably higher when compared to field and laboratory studies such as Borges (1985, 1986b), Borges \& Macedo (1986) and Borges et al. (1986). The higher fertility found in this work might be explained by the following conditions: 1) laboratory-reared females are usually less fertile than free-living females, depending on the number of generations (Sреснт et al. 2006b); 2) mating success and fertility are higher if several couples are kept together (e.g., three couples per cage) instead of just one (SANTOS et al. 1988). Although we used free-living females to evaluate fertility we believe that the environmental resistance normally experienced in nature such as the occurrence of natural enemies (predators, parasitoids, etc), diseases and the adverse climatic conditions had little or no impact on fertility because all free living females were maintained under controlled conditions, at the laboratory, after they were captured. However, it has been established that these factors can significantly affect fertility (Borges 1986b, 1988, 1990a, b, Borges \& Macedo 1986, Borges et al. 1986).

\section{Larval Stage}

The long larval developmental period, corresponding to approximately $40 \%$ of total life cycle (Fig. 1, Table I), is very common in Hemileucinae moths and resulted in several larval anti-predator strategies including mimetic coloration, cryptic habits and gregarious behavior (see images in Figs 3 and 4). In addition, the larvae possessed specialized structures used to inoculate glandular urticating toxins (BERNAYS \& JANZEN 1988), as observed by Borges \& MACEDo (1986). 
The larvae developed through six instars under the same temperature conditions, in accordance with Borges (1986a). The female larvae took more than two days to develop when compared to males, although it could be noted only during the fourth instar onward, but not during the prepupal stage (Table II). A longer developmental period of female larvae was also noted by Borges (1986a), but only in the fifth and sixth instars.

The developmental period of the first instar larva of $D$. araucariae was remarkably longer than other instars (Table II), when the larvae had to move from the place they hatch (trunks or branches) to the twigs, where they start to feed on new leaves (Borges 1986b). However, as also noted by Borges (1986a), the developmental period of each forthcoming instar increased progressively along of the rest of the larval development.

Table II. Duration of each larval instar and prepupa stage for females and males of Dirphia araucariae reared at $20 \pm 1{ }^{\circ} \mathrm{C}, 70 \pm$ $10 \%$ RU with 12:12 photoperiod.

\begin{tabular}{lccc}
\hline \multirow{2}{*}{$\begin{array}{c}\text { Developmental } \\
\text { stage }\end{array}$} & \multicolumn{3}{c}{ Duration (days) } \\
\cline { 2 - 4 } & Females (56) & Males (48) & Significance \\
\hline II & $14.21 \pm 1.09$ & $13.89 \pm 0.85$ & $\mathrm{~ns}$ \\
III & $7.66 \pm 0.51$ & $7.48 \pm 0.65$ & $\mathrm{~ns}$ \\
IV & $7.96 \pm 0.63$ & $7.75 \pm 0.63$ & $\mathrm{~ns}$ \\
V & $8.76 \pm 0.78$ & $8.45 \pm 0.74$ & $*$ \\
VI & $11.93 \pm 1.09$ & $11.43 \pm 1.07$ & $*$ \\
Prepupa & $12.18 \pm 0.81$ & $11.66 \pm 1.07$ & $*$ \\
\hline Total & $6.98 \pm 1.21$ & $6.68 \pm 1.09$ & $\mathrm{~ns}$ \\
\hline Means were compare & $69.69 \pm 2.58$ & $67.37 \pm 2.02$ & $* *$ \\
\hline
\end{tabular}

Means were compared by the Student's t-test, at a significance level of $p<0.05$ (ns $p>0.05 ;{ }^{*} p<0.05 ;{ }^{* *} p<0.01$ ).

The width of the cephalic capsules varied between sexes and was more pronounced from the fourth instar onward (Table III). This feature indicates that sexual dimorphism occurs during the larval stage, although it is more conspicuous during pupal and adult stages in D. araucariae (BORGes 1985, Borges et al. 1986a) and other Hemileucinae moths (Lemaire 2002). The mean growth rate was very similar between sexes (Table III) but, intriguingly, it was slightly higher at both the beginning and the end of the larval stage, which is partially in accordance with Borges (1986a). The mean growth rate of $D$. araucaraiae (i.e. 1.42) is very similar to other Hemileucinae moths [e.g., Automeris Hübner, 1819 (SРеснт et al. 2006b, 2007b), Hylesia Hübner, 1820 (Sреснт et al. 2006a, 2007a), Leucanella Lemaire, 1969 (Sреснт et al. 2009), Molippa Walker, 1855 (Sресht et al. 2010) and Periga Walker, 1855 (Specht et al. 2011)], and was consistent with expectation for Lepidoptera in general ( 1.45) (DYAR 1890).

The considerably large number of surviving larvae (Table I) is probably related to the way which the rearing was accomplished. We have accumulated vast experience by rearing other species of Hemileucinae moths, including $D$. araucariae, during many years until we sufficiently optimized our methods to minimize interferences and reduce the stress during larval development. Thus, it is highly probable that the know-how acquired during all these years resulted in a higher survivor rate when compared to Borges $(1985,1986$ a) (i.e. $76.11 \%)$, although host plant-related features or unknown factors may also had contributed. The lower survival rate at the end of the larval development, also called prepupa stage, (Table I) was not in accordance with Borges (1985), which found a lower rate during the beginning of the larval development. It is worth pointing out that it might be related to the right quantity of litter, which is used by the larvae at the beginning of the prepupal stage (Fig. 4) in order to build its pupal chambers and develop into the pupa stage.

\section{Pupal Stage}

The sex ratio $(0.502 \pm 0.045)$ did not significantly deviate from the $1: 1$ ratio $\left(\chi^{2}=0.800 \times 10^{6} \mathrm{p}<0.01\right)$, given that 201 females and 197 males originated from the 11 analyzed egg clusters (398 larvae). However, the sex ratio was considerably different between egg clusters, with values ranging from 0.34 to 0.58 .

The pupal stage corresponded to more than one third of the total life cycle (Figs 2-7). Although the pupae developed under controlled temperature, not all of them developed at the

Table III. Mean cephalic capsule width and growth rate of each instar for females and males of Dirphia araucariae reared at $20 \pm 1{ }^{\circ} \mathrm{C}, 70$ $\pm 10 \%$ RU with $12: 12$ photoperiod.

\begin{tabular}{|c|c|c|c|c|c|c|c|}
\hline Instar & Females (56) & Growth rate & Males (48) & Growth rate & & Total (104) & Growth rate \\
\hline$I$ & $1.05 \pm 0.02$ & - & $1.04 \pm 0.02$ & - & ns & $1.05 \pm 0.02$ & - \\
\hline II & $1.49 \pm 0.06$ & 1.41 & $1.46 \pm 0.07$ & 1.40 & ns & $1.48 \pm 0.07$ & 1.41 \\
\hline III & $2.09 \pm 0.08$ & 1.40 & $2.06 \pm 0.08$ & 1.40 & ns & $2.08 \pm 0.08$ & 1.40 \\
\hline IV & $2.93 \pm 0.11$ & 1.39 & $2.88 \pm 0.11$ & 1.39 & $*$ & $2.91 \pm 0.11$ & 1.39 \\
\hline V & $4.06 \pm 0.13$ & 1.38 & $3.97 \pm 0.13$ & 1.38 & $* *$ & $4.02 \pm 0.13$ & 1.38 \\
\hline $\mathrm{VI}$ & $6.07 \pm 0.14$ & 1.49 & $5.93 \pm 0.11$ & 1.49 & ** & $6.01 \pm 0.14$ & 1.49 \\
\hline Mean & & 1.42 & & 1.41 & & & 1.41 \\
\hline
\end{tabular}

Means were compared by the Student's t-test, at a significance level of $\mathrm{P}<0.05$ (ns $\left.\mathrm{p}>0.05 ;{ }^{*} \mathrm{p}<0.05 ;{ }^{* *} \mathrm{p}<0.01\right)$. 

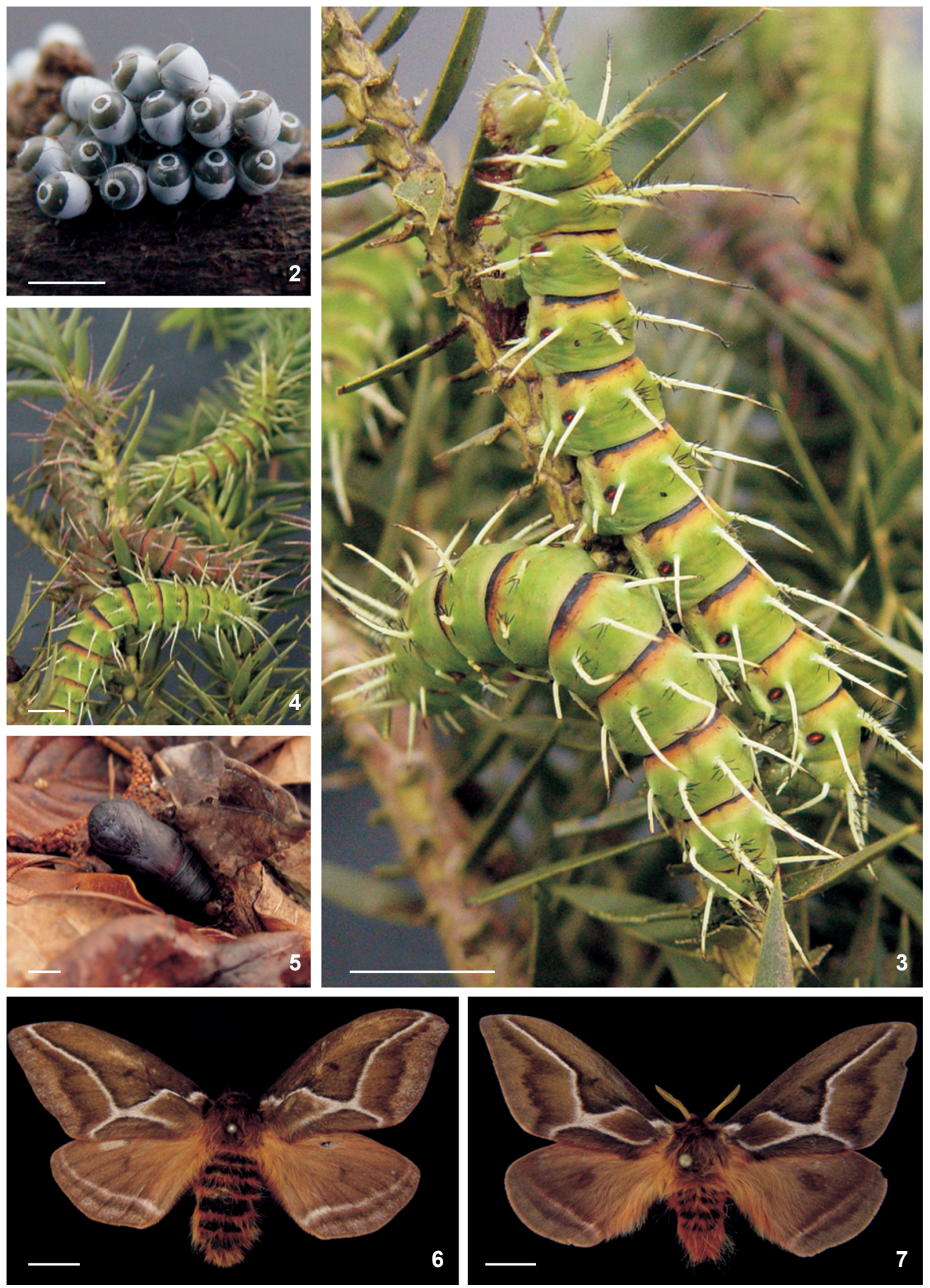

Figures 2-7. Dirphia araucariae: (2) egg cluster; (3) sixth instar larvae; (4) sixth instar larvae and darker larvae at the end of the larval stage (prepupa stage); (5) pupa in the Araucariae Pine Forest litter; (6) female; (7) male. Scale bar: $1 \mathrm{~cm}$.

same time, resulting in a large variation in the pupal developmental period (Table I). Pupal weight and pupal developmental period were weakly correlated with each other in females $(\mathrm{r}=$ $0.636, p<0.01,54$ d.f. $)$ as well as in males $(r=0.345, p<0.05,46$ d.f.). It is worth pointing out that according to Borges (1986b), temperature and developmental period are strongly correlated with each other, with populations that develop through the winter as pupae going through a longer pupal stage (diapause). 
This phenomenon is widespread in the Hemileucinae and can be more commonly found under natural conditions (SРеснт et al. 2006b, 2007b).

A shorter pupal developmental period in females than in males was statistically corroborated (Table IV). Even though it has been previously mentioned by Borges $(1985,1986 a)$, the author was not able to confirm it statistically. Based on the results of Borges $(1985,1986 a)$ and on our own results, we believe that this sex-related biological difference may be characterized as an evolutionary trade-off, which balance the duration of both stages between sexes. Therefore, considering the larval and pupal developmental periods at the same time, we were not able to find a statistically significant difference between females and males (Table IV), which is in accordance with BorgEs $(1985,1986 a)$.

Female pupae were heavier than males and this difference was statistically corroborated (Table IV). Furthermore, Borges (1985) and Borges et al. (1986) reported that, in addition to weight, differences in width and volume are also related to sexual dimorphism during the pupal stage. It is worth to emphasize that other Hemileucinae pupae also present sexual dimorphism (e.g., Zanuncio et al. 1994, Sреснt et al. 2006a, b, $2007 \mathrm{a}, \mathrm{b}, 2009,2010,2011)$ and such dimorphism may be related to the fact that adult females are larger than adult males.

The fact that all pupae have completed their development can be explained by our efforts to improve the rearing conditions, such as the attempt to rear the larvae using different kinds of substrate (e.g., vermiculite, sand, soil etc), and specially by following the methodology proposed by BORGES $(1985,1986 \mathrm{a}$, b), which determined the most suitable rearing temperature. It is also worth pointing out that laboratory rearing conditions must emulate the environmental conditions which are normally experienced by $D$. araucariae in nature. Therefore, we tried to reproduce natural conditions of a native $A$. angustifolia forest.

\section{Adult stage}

The life span of the adults (Figs 6 and 7) was very short (Table I), corresponding to $5 \%$ of total life cycle (Figs 2-7). A short adult developmental period is common in the Hemileucinae (Lemaire 2002) and is related to the fact that they do not feed as adults, with their activities during adult stage being restricted to reproduction such as courtship, mating and oviposition.

As in D. moderata, reared on Eucalyptus cloeziana F. Muell. leafs (Pereira et al. 2008), the adult developmental period of $D$. araucariae was statistically significantly longer in females than in males $(\mathrm{p}<0.01)$. The duration of oviposition period (Table V) was similar to Borges et al. (1986), i.e. 2 days (preoviposition), 5.58 days (oviposition) and 2.75 days (postoviposition), considering the same rearing temperature.

Table V. Average life span for adult females and males, duration of oviposition period (in days) and fecundity of 20 couples of Dirphia araucariae reared at $20 \pm 1{ }^{\circ} \mathrm{C}, 70 \pm 10 \% \mathrm{RU}$ with $12: 12$ photoperiod.

\begin{tabular}{|c|c|c|c|}
\hline Sex & Parameter & Mean & Range \\
\hline \multirow[t]{7}{*}{ Female } & Life span * & $9.85 \pm 1.75$ & $6-12$ \\
\hline & Total Fecundity ${ }^{(1+2)}$ & $358.45 \pm 48.73$ & $238-425$ \\
\hline & Fecundity (laid eggs) $^{1}$ & $302.55 \pm 74.25$ & $142-412$ \\
\hline & $\begin{array}{l}\text { Fecundity (eggs held } \\
\text { in the abdomen) }{ }^{2}\end{array}$ & $55.90 \pm 46.82$ & $0-201$ \\
\hline & Postoviposition & $1.15 \pm 0.93$ & $0-2$ \\
\hline & Oviposition & $6.6 \pm 2.18$ & $3-10$ \\
\hline & Preoviposition & $2.1 \pm 0.30$ & $2-3$ \\
\hline Male & Life span * & $6.9 \pm 1.16$ & $5-9$ \\
\hline
\end{tabular}

Means were compared by the Student's t-test, at a significance level of $p<0.05$ (ns $=p>0.05 ;{ }^{*} p<0.05$ ).

The mean number of eggs produced by female, considering 20 laboratory-reared couples (F1 generation), was $358.45 \pm$ 48.73 and the mean number of laid eggs and eggs held in the abdomen were $302.55 \pm 74.26$ and $55.4 \pm 46.83$, respectively (see Table $\mathrm{V}$ for details). A strong negative correlation was obtained between the number of laid eggs and the number of eggs held in the abdomen $(r=-0.767, p<0.01$, d.f. 38), whereas the reduced fecundity is due to a considerably high number of eggs held in the female abdomens. This pattern was also observed in D. moderata (ZANUNCIO et al. 1994) and, according to the observations by SANTOS et al. (1988) on H. nanus, it is related to mating viability. Those authors found that, when three couples were kept together in the same cage, there were no eggs held in the abdomens (100\% fecundity). However, by using only one couple per cage, the fecundity rate dropped to $77.68 \%$, which is similar to our results (i.e., $84.4 \%$, not shown in Table V). Therefore, when studying fertility of laboratoryreared females, it is important to take into account not only the eggs laid but also the eggs held in the abdomen.

Table IV. Mean duration (in days) of pupal stage and larval + pupal stage, and mean pupal weight for females and males of Dirphia araucariae reared at $20 \pm 1{ }^{\circ} \mathrm{C}, 70 \pm 10 \% \mathrm{RU}$ with $12: 12$ photoperiod.

\begin{tabular}{lccccc}
\hline \multicolumn{1}{c}{ Parameter } & Female (108) & Range & Male (120) & Range & Significance \\
\hline Pupal stage & $61.05 \pm 7.73$ & $46-79$ & $64.10 \pm 6.83$ & $48-79$ & $*$ \\
Pupal + larval stage & $130.75 \pm 7.96$ & $114-149$ & $131.48 \pm 7.46$ & $115-148$ & ns \\
Pupal weight & $5.36 \pm 0.592$ & $2.69-6.26$ & $3.70 \pm 0.50$ & $2.40-4.79$ & $*$ \\
\hline
\end{tabular}

Means were compared by the Student's t-test, at a significance level of $P<0.05$ (ns $p>0.05$; ${ }^{*} p<0.05$ ). 
Although Borges et al. (1986) and Borges \& MACEDo (1986) found a strikingly lower mean number of laid eggs than we found at the same temperature (i.e. 243.5), their data was based on adults from pupae collected during a population outbreak. Thus, it is very likely that larvae would have experienced feeding restriction, which could affect adult traits, including fecundity (FANTINOU et al. 2008). In fact, we found a strong positive correlation between pupal weight and total fecundity $(\mathrm{r}=0.818$, $\mathrm{p}<0.01$, d.f. 38), which indicates that larval feeding restriction has a negative effect on fecundity and explain why Borges et al. (1986) found a low fecundity.

\section{Biotic potential and life fertility table}

Considering a 1:1 sex ratio, no environmental resistance and the following values for the components of the biotic potential equation, $\mathrm{d}=275.81$ and $\mathrm{n}=2.19$, the biotic potential (BP) of $D$. araucariae is $48,731.08$ insects/female/year. This value is very low when compared to other Hemileucinae moths like Automeris illustris (Walker, 1855), BP $=8.719 \times 10^{6}$ (SРECHT et al. 2006b), and Automeris naranja Schaus, BP $=1.195 \times 10^{6}$ (SРеснт et al. 2007b). According to Borges \& Macedo (1986) the low biotic potential might explain why $D$. araucariae usually does not reach the economic damage level, except through occasional epizootic outbreaks when more than one generation takes place in a single year.

The highest value of population growth rate was observed at the beginning of the $23^{\text {rd }}$ week of life (Fig. 8) or between the third and fifth day of the adult stage, when females laid their eggs. The number of females in two consecutive generations, or the net reproductive rate (Ro) was 117.21, and the mean duration of one generation (T) was 162.75 days; the innate capacity of increase in numbers $\left(\mathrm{r}_{\mathrm{m}}\right)$ was 0.21 , and the finite rate of natural increase $(\lambda)$ was 1.23 .

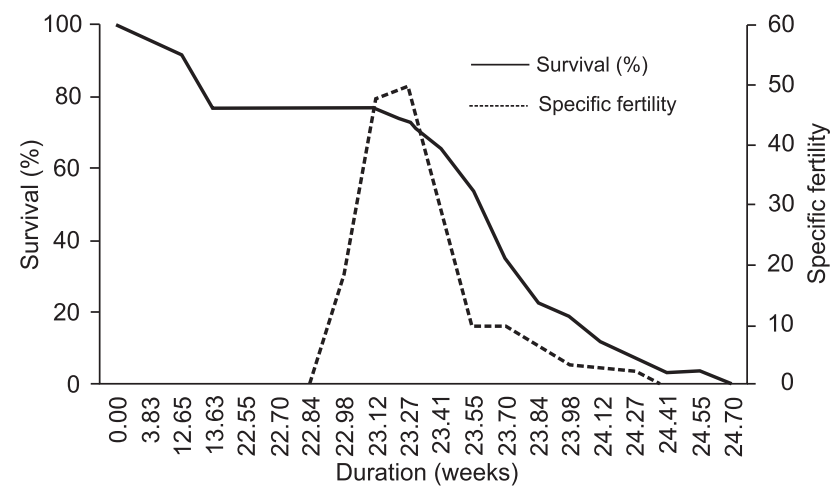

Figure 8. Relation between fertility $(\mathrm{mx})$ and survival rate $(\mathrm{Ix})$ of Dirphia araucariae reared at $20 \pm 1{ }^{\circ} \mathrm{C}, 70 \pm 10 \%$ RU with $12: 12$ photoperiod.

This work is part of a long term research about the Hemileucinae moths which aims to understand their develop- mental biology, providing valuable information for agricultural and forest entomology, conservation biology, ecology and taxonomy. In conclusion, the evaluated biological parameter of $D$. araucariae indicates that it is not able to cause primary damages in A. angustifolia forests. However, further works are needed to clarify the biological differences found between geographical populations, and to understand whether the conditions that lead to outbreaks are environmental or physiological.

\section{ACKNOWLEDGMENTS}

We especially thanks to Marcio R. Pie (Universidade Federal do Paraná, Brazil) and Carla M. Penz (University of New Orleans, USA) for grammar revisions.

\section{LITERATURE CITED}

Bernays, E.A. \& D.H. Janzen. 1988. Saturniid and Sphingid Caterpillars: Two Ways to Eat Leaves. Ecology 69: 1153-1160.

Borges, J.D. 1985. Biologia de Dirphia araucariae em laboratório. Pesquisa Agropecuária Brasileira 20: 155-158.

Borges, J.D. 1986a. Influência da temperatura no desenvolvimento de Dirphia araucariae. Pesquisa Agropecuária Brasileira 21: 587-592.

Borges, J.D. 1986b. Aspectos da biologia e comportamento de Dirphia araucariae em seu habitat natural. Anais das Escolas de Agronomia e Veterinaria 14/16: 45-51.

Borges, J.D. 1988. Novos parasitoides em ovos de Dirphia araucariae (Lep.; Attacidae). Anais das Escolas de Agronomia e Veterinaria 18: 67-71.

Borges, J.D. 1990a. Entomofauna do Pinheiro-do-Paraná. Pesquisa Agropecuária Brasileira 25: 201-206.

Borges, J.D. 1990b. Parasitismo em ovos e pupas de Dirphia araucariae. Pesquisa Agropecuária Brasileira 25: 243-246.

Borges, J.D. \& J.H.P. MACEDO. 1986. Ocorrência de Dirphia araucariae em Araucaria angustifolia no município de Congonhinhas, PR. Pesquisa Agropecuária Brasileira 21: 101-104.

Borges, J.D.; M.F. Carneiro \& A.A. Almeida. 1986. Dados sobre as pupas e comportamento dos adultos de Dirphia araucariae. Pesquisa Agropecuária Brasileira 21: 467-471.

Dyar, H.G. 1890. The number of molts of lepidopterous larvae. Psyche 5: 420-422.

EnRight, N.J. \& R.S. Hill. 1995. Ecology of the Southern Conifers. Melbourne, Melbourne University Press.

Fantinou, A.A.; D.C. Perdikis; N. Stamogiannis. 2008. Effect of larval crowding on the life history of Sesamia nonagrioides (Lepidoptera: Noctuidae). European Journal of Entomology 105: 626-630.

FARJON, A. 2006. Araucaria angustifolia. In: IUCN (Ed.). IUCN Red List of Threatened Species. Version 2011.2. Available on-line at: www.iucnredlist.org [Accessed: 10/XI/2011].

Lemaire, C. 2002. The Saturniidae of America - Hemileucinae. Keltern, Goecke \& Evers, 1388p. 
MACEDO, J.H.P. 1977. Conhecimentos para planejar a proteção florestal. Floresta 8: 54-57.

Mattos, J.R. 1972. O pinheiro brasileiro. São Paulo, Grêmio Politécnico, 638p.

Pereira, F.F.; A.J.V. Zanuncio; J.P.M. Felipe; A.S. Lorenzon; G.C. Canevari. 2008. Desenvolvimento e reprodução de Dirphia moderata (Lepidoptera: Satutniidae) em Eucalyptus cloeziana e Psidium guajava em laboratório. Revista árvore 32: 11191124.

SAntos, G.P.; N. Anjos \& J.C. Zanuncio. 1988. Biologia de Hylesia nanus (Walker, 1855) (Lepidoptera: Attacidae), desfolhadora de cutieira (Joannesia princeps: Euphorbiaceae). Revista Ceres 35: 479-485.

Santos, G.P.; J.E. Zanuncio; H. FantuzZi Neto \& T.C. Zanuncio. 1993. Aspectos biológicos e morfológicos de Dirphiopsis eumedidoides (Vuillot, 1893) (Lepidoptera: Saturniidae) em folhas de Eucalyptus grandis. Revista Árvore 17: 351-357.

Silveira-neto, S.; O. NaKano; D. Barbin \& N.A. Villa Nova. 1976. Manual de ecologia dos insetos. São Paulo, Editora Agronômica Ceres, 420p.

Specht, A.; A.C. Formentini \& E. Corseull. 2006a. Biologia de Hylesia nigricans (Berg) (Lepidoptera, Saturniidae, Hemileucinae). Revista Brasileira de Zoologia 23: 248-255.

Specht, A.; A.C. Formentini \& E. Corseuil. 2006b. Biologia de Automeris illustris (Walker) (Lepidoptera, Saturniidae, Hemileucinae). Revista Brasileira de Zoologia 23: 537-546.

Specht, A.; A.C. Formentini \& E. Corseuil. 2007a. Biological aspects of Hylesia metapyrrha (Lepidoptera: Saturniidae: Hemileucinae), in laboratory. Brazilian Journal of Biology 67: 173-177.

Submitted: 02.VII.2012; Accepted: 18.II.2013.

Editorial responsibility: Kleber Del Claro
Specht, A.; A.C. Formentini \& E. Corseuil. 2007b. Biologia e aspectos morfológicos dos estágios imaturos de Automeris naranja Schaus (Lepidoptera, Saturniidae, Hemileucinae). Revista Brasileira de Zoologia 24: 537-545.

Specht, A.; E. Corseuil \& A.C. Formentini. 2008. 5 - Saturniidae, Hemileucinae, p. 81-131. In: A. Specht; E. Corseuil \& H.B. Abella (Eds). Lepidópteros de Importância Médica - Principais espécies no Rio Grande do Sul. Pelotas, USEB. 220p.

Specht, A.; E. Corseuil; A.J. Benedetti; G. Poletto \& A.C. Formentini. 2009. Aspectos biológicos e morfológicos de Leucanella viridescens (Lepidoptera: Saturniidae: Hemileucinae). Zoologia 26: 25-31.

Specht, A.; A.C. Formentini \& A.J. Benedetti. 2010. Biology and morphology of Molippa cruenta (Lepidoptera: Saturniidae) in the laboratory. Zoologia 27: 347-352.

Specht, A.; L.M. Lorini; E. Fronza \& G. Poletto. 2011. Biological aspects of Periga circumstans Walker, 1855 (Lepidoptera: Saturniidae: Hemileucinae) with larvae reared on khaki and mate-plant leaves. Brazilian Journal of Biology 71: 10151022.

Vila, W.M. \& C.T. Carvalho. 1972. Predação da lagarta do "Pinheiro Brasileiro". Brasil Florestal 3: 25-28.

Zanuncio, J.C.; G.P. Santos; L.G. Batista \& W.L. Gasperazzo. 1992. Alguns aspectos da biologia de Dirphia rosacordis (Lepidoptera: Saturniidae) em folhas de eucalipto. Revista Árvore 16: 112117.

Zanuncio, T.V.; J.C. Zanuncio; I.A. Meira \& F.S. Araújo. 1994. Caracterização das fases larval e adulta de Dirphia avicula (Lepidoptera: Saturniidae) em folhas de Eucalyptus urophylla. Revista Árvore 18: 153-158. 